\title{
Intervensi selama kehamilan untuk mencegah kelahiran prematur: Systematic literature review
}

\author{
Tetti Solehati ${ }^{*}$, Hana Giriutami, Meideline Chintya, Siti Haiva Alawiyah, Selvia Nurfauzan, Riftania Aulia \\ Puri, Muhammad Iqbal Assafa, Cecep Eli Kosasih
}

Fakultas Keperawatan Universitas Padjadjaran Bandung Jawa Barat.*Email: tetti.solehati@unpad.ac.id

\begin{abstract}
Interventions during pregnancy to prevent preterm birth: A systematic literature review
\end{abstract}

Background: Premature birth is a major factor that contributes to mortality of newborns globally and impacts long-term to health problems for survivors. Premature births have increased in the last 20 years where the phenomenon is equivalent to 1 in 10 births each year. Therefore, prevention of preterm labor is important given to pregnant women.

Purpose: This study aimed to find out effectiveness interventions during pregnancy to preventing preterm birth.

Method: The design used literature review, articles were collected using search engines such as Academic Search Complete (EBSCO) as many as 78 articles, CINAHL (EBSCO) 36 articles, Science Direct 593 articles, and PUBMED 55 articles. From the predetermined article criteria, it found 3 articles from 762 that correspond to different interventions, namely consumption of progesterone supplements, cognitive behavior to reduce cigarette smoke exposure, and early detection in pregnant women at high risk of preterm delivery.

Results: The result showed that there were 3 interventions in the effort to prevent preterm birth, namely: progesterone supplementation therapy, the intervention to reduce exposure to cigarette smoke in the environment, and identification and management of early detection of fast on pregnant women at high risk of preterm birth.

Conclusion and Recommendation: several interventions can use in preventing preterm birth of pregnant women effectively, such as progesterone supplementation, reduction in cigarette smoke exposure in pregnant women, and early detection of pregnancy. Further research is suggested by involving the role of the family in preventing premature birth

\section{Keywords: Intervention; Pregnant women; Premature birth; Prevention}

Pendahuluan: Kelahiran prematur merupakan faktor mayor yang berkontribusi terhadap kematian bayi baru lahir secara global dan berdampak pada masalah kesehatan jangka panjang untuk bayi yang selamat. Kelahiran prematur mengalami peningkatan pada 20 tahun terakhir dimana fenomenanya setara dengan 1 dari 10 kelahiran tiap tahunnya. Oleh karena itu pencegahan persalinan prematur penting diberikan kepada ibu hamil.

Tujuan: untuk mengetahui intervensi efektif selama kehamilan dalam mencegah persalinan prematur.

Metode: Desain yang digunakan adalah literature review, artikel dikumpulkan menggunakan mesin pencarian seperti Academic Search Complete (EBSCO) 78 articles, CINAHL (EBSCO) 36 articles, Science Direct 593 articles, dan PUBMED 55 articles. Dari kriteria inklusi artikel yang telah ditentukan, ditemukan 3 artikel dari 762 yang sesuai dengan intervensi yang berbeda.

Hasil: menunjukan bahwa ada 3 intervensi dalam upaya mencegah kelahiran prematur yaitu: terapi suplementasi progesteron, intervesi pengurangan paparan asap rokok pada lingkungan, dan identifikasi dan penatalaksanaan deteksi dini secara cepat terhadap ibu hamil yang berisiko tinggi lahir prematur.

Simpulan dan Saran: Intervensi pemberian suplemen progesteron, pengurangan paparan asap rokok di lingkungan ibu hamil, dan deteksi dini pada kehamilan terbukti efektif dalam mencegah kelahiran prematur pada ibu hamil. Disarankan penelitian lebih lanjut dengan melibatkan peran keluarga dalam mencegah kelahiran prematur.

Kata Kunci: Ibu hamil; Intervensi; Prematur; Pencegahan 


\section{PENDAHULUAN}

Prematur didefinisikan sebagai bayi yang lahir hidup sebelum 37 minggu kehamilan selesai (WHO, 2018). Kelahiran prematur merupakan faktor mayor yang berkontribusi terhadap kematian bayi baru lahir secara global dan berdampak pada masalah kesehatan jangka pendek dan jangka panjang untuk bayi yang selamat (Medley, Vogel, Care, \& Alfirevic, 2018; WHO, 2018). Sekitar 1 juta anak meninggal setiap tahun karena komplikasi kelahiran prematur (1). Komplikasi kelahiran prematur merupakan penyebab utama kematian di antara anak-anak di bawah usia 5 tahun, yang bertanggung jawab atas sekitar 1 juta kematian pada tahun 2015 (1). Semakin singkat masa kehamilan maka semakin besar juga resiko kematian dan morbiditas untuk bayi. Bayi prematur memiliki resiko kematian di tahun pertama kehidupan terutama prematuritas (Lassi, Middleton, Crowther, \& Bhutta, 2015).

Setengah dari bayi prematur yang lahir kurang dari 32 minggu meninggal karena kurangnya perawatan yang layak dan hemat biaya, dukungan ibu untuk memberikan ASI ekskusif, dan perawatan dasar (WHO, 2018). Di negara-negara yang mempunyai penghasilan tinggi, hampir semua bayi prematur bisa bertahan hidup karena penggunaan teknologi yang optimal (WHO, 2018). Selain memiliki risiko kematian yang lebih tinggi, bayi yang dilahirkan premature memiliki risiko disabilitas motorik jangka panjang, pendengaran,visual, sikap, kognitif, emosi sosial, masalah kesehatan, dan masalah pertumbuhan jika dibandingkan dengan bayi normal (Zhang et al., 2012).

Prevalensi global Bayi baru lahir Rendah BBLR masih tinggi yaitu $15,5 \%$ atau berjumlah sekitar 20 juta bayi BBLR yang lahir setiap tahun, 96,6\% di antaranya di negara berkembang (Fayed, 2016), termasuk didalamnya bayi lahir prematur. Hampir di semua negara dengan data yang dapat diandalkan, angka kelahiran prematur meningkat, diperkirakan 15 juta bayi lahir prematur setiap tahunnya atau sekitar 1 dari 10 kelahiran (WHO, 2018). Di 184 negara, tingkat kelahiran prematur berkisar dari $5 \%$ hingga $18 \%$ bayi yang lahir (WHO, 2018). Banyak faktor resiko yang berkontribusi pada kelahiran premature seperti: kehamilan ganda, infeksi, dan kondisi kronis seperti diabetes, hypertensi (WHO, 2018), dan paparan asap rokok (Noriani, Putra, \& Karmaya, 2015). Sebenarnya, kematian pada bayi premature dapat diatasi apabila penatalksanaannya tepat. Tiga perempat dari kematian akibat komplikasi pada bayi prematur dapat dicegah dengan melakukan intervensi yang efektif (WHO, 2018). Lebih baik lagi apabila intervensi diarahkan pada pencegahan terjadinya persalinan premature pada ibu didalam masa kehamilannya. Penelitian ini bertujuan untuk mengetahui intervensi efektif selama kehamilan dalam mencegah persalinan prematur.

\section{METODE PENELITIAN}

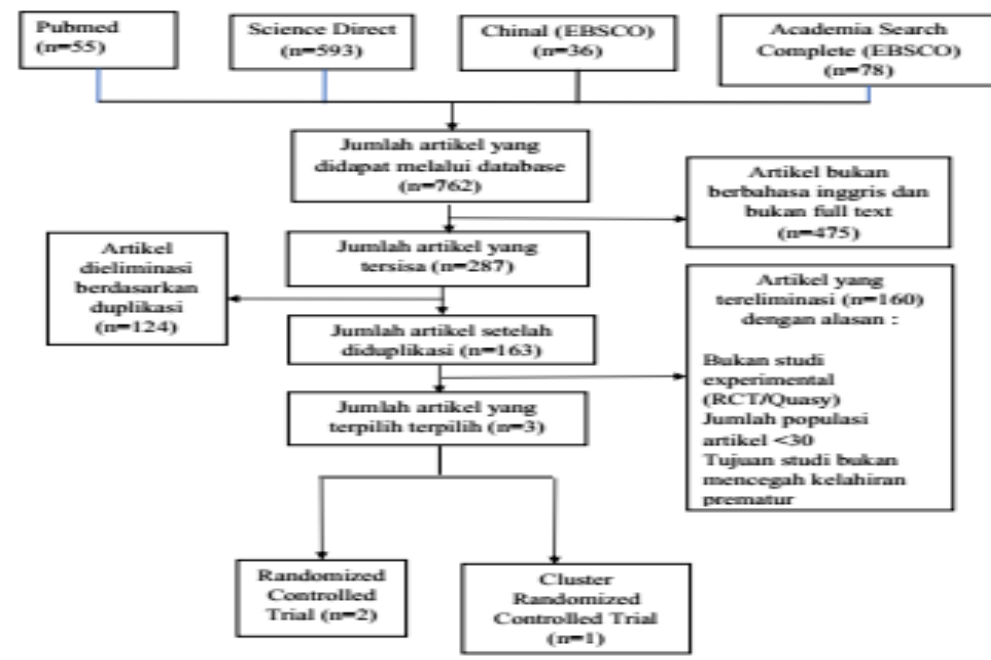

Gambar 1. PRISMA Flow Diagram dalam menseleksi artikel (Moher, Liberati, Tetzlaff, \& Altman, 2009)

Tetti Solehati*, Hana Giriutami, Meideline Chintya, Siti Haiva Alawiyah, Selvia Nurfauzan, Riftania Aulia Puri, Muhammad lqbal Assafa, Cecep Eli Kosasih

Fakultas Keperawatan Universitas Padjadjaran Bandung Jawa Barat.*Email: tetti.solehati@unpad.ac.id 
Penyusunan Literature Review dengan cara melakukan pencarian artikel menggunakan database electronic yaitu Pubmed, Science Direct, Chinal (Ebsco) dan Academic Search Complete (Ebsco). Menggunakan kata kunci dalam Bahasa Inggris "Pretem", "Prevention/ Treatment/ Prevention", "Randomized Controlled Trial". Kriteria inklusi artikel yang diambil antara lain Full text, artikel berbahasa Inggris, di publikasi antara tahun 2010-2020, RCT atau quasi eksperimen, merupakan intervensi kelahiran premature selama kehamilan, dan sampel pada kelompok minimal 30. Menurut (Hutchins, Brown, Mayberry, \& Sollecito, 2015), bahwa ukuran sampel dalam studi simulasi idealnya adalah minimal 30 dan maximal 200. Hasil pencarian artikel yang ditemukan pada Pubmed sebanyak 762 artikel didapatkan dari Pubmed 55 artikel, Science Direct sebanyak 593 artikel, Chinal (Ebsco) sebanyak 36 artikel, dan Academia Search Complete (Ebsco) sebanyak 78 artikel.

Setelah dilakukan seleksi ada 475 artikel yang tidak fulltex dan tidak berbahasa inggris sehingga tersisa 287 artikel. Setelah itu tim penulis melakukan cek duplikasi sehingga tersisa sebanyak 163 artikel, yaitu: Pubmed sebanyak 40 artikel, Science Direct sebanyak 33 artikel, Chinal (Ebsco) sebanyak 47 artikel dan Academic Search Complete (Ebsco) sebanyak 43 artikel. Analisa artikel berfokus pada intervensi yang berpengaruh terhadap pencegahan kelahiran premature selama kehamilan. Artikel yang telah ditemukan, diidentifikasi dan disaring oleh tim penulis kemudian dinilai kelayakan studi dengan menggunakan The Joanna Briggs Institute (JBI) Critical Appraisal Tools for Randomized Controlled Trials (Institute, 2017), dan mengekstaksi data ke dalam tabel dengan judul yang telah ditentukan. Sehingga diperoleh 3 artikel yang memenuhi syarat. Semua tim penulis membahas artikel tersebut apabila ada ketidaksesuaian.

\section{HASIL}

Berdasarkan 3 artikel yang terpilih dengan jenis penelitian randomized controlled trial yang dilaksanakan di negara Iran, India dan America didapatkan tiga intervensi yang berbeda untuk mencegah kelahiran premature. Artikel pertama adalah intervensi pemberian suplementasi progesterone dapat mencegah kelahiran premature. Penelitian ini dilakukan oleh Ibrahim et all (2010) di negara Iran. Intervensi pemberian suplemen progesterone dengan nama cidolut depot. Dengan cara grup A (kelompok progesterone) : 25 wanita menerima dosis standar antenatal 17-o-hidroksi progesterone caproate (Cidolut depot) $250 \mathrm{mg}$ intramuskuler per minggu sampai 36 minggu kehamilan. Grup B (kelompok placebo) : 25 wanita menerima standar dosis dari placebo antenatal secara intramuscular perminggu sampai 36 minggu atau persalinan (Ibrahim, Ramy, \& Younis, 2010). Artikel kedua merupakan penelitian intervensi perilaku-kognitif (cognitivebehavioural) oleh El-Mohandes et all (2010) Penelitian ini bertujuan untuk menguji efektivitas dari perilaku-kognitif (cognitive-behavioural) dalam mengurangi paparan asap rokok (environmental tobacco smoke/ ETSE) guna meningkatkan hasil kehamilan pada wanita enis kulit hitam. Dilakukan di 6 klinik yang berada di Washington DC. Sampel sebanyak 1044 orang yang memenuhi kriteria penelitian, dengan kelompok intervensi sebanyak 521 orang dan kelompok kontrol sebanyak 523 orang. Intervensi dilakukan selama perawatan prenatal oleh tim penasihat kehamilan, psikologi dan pekerja sosial. Intervensi yang diberikan pada kelompok Intervensi difokuskan pada memperkenalkan strategi dalam rumah untuk menghilangkan atau meminimalkan paparan asap rokok ke ibu hamil. Intervensi tersebut dilakukan melalui bermain peran dan praktek keterampilan negosiasi dengan perokok. Ibu diberitahu tentang potensi risiko dari ETSE untuk ibu dan janin, serta risiko terhadap bayi baru lahir.Selanjutnya untuk kelompok kontrol hanya diberikan perawatan biasa (El-Mohandes, Kiely, Blake, Gantz, \& El-Khorazaty, 2010).

Artikel selanjutnya adalah penelitian yang dilakukan oleh Patel et all (2017) di negara India dengan melakukan deteksi dini pada wanita yang beresiko melahirkan premature sebanyak 15120 yang terdaftar di Maternal Newborn Health Registry. Partisipan dibagi menjadi dua kelompok yaitu kelompok control cluster sebanyak 7692 dan kelompok intervention cluster sebanyak 7424 . Pada kelompok intervention cluster, jumlah partisipan menjadi 7050 karena sebelumnya dilakukan pengeliminasian dengan kriteria eksklusi: keguguran ( $\mathrm{N}=298)$, tidak ada informasi mengenai HPHT, TP, dan berat lahir $(\mathrm{N}=70)$, dan terakhir usia kehamilan <24 minggu atau $>36$ minggu $(\mathrm{N}=6)$. Pada kelompok control cluster tidak diberi perlakuan, sedangkan perlakuan pada kelompok intervention cluster dilakukan dengan cara pemantauan/deteksi dini oleh petugas kesehatan kepada ibu hamil yang terdiri dari 4 komponen yaitu: 
1. Pelatihan petugas kesehatan di berbagai tingkatan mengenai tanda gejala persalinan prematur. Tanda gejala tersebut antara lain nyeri perut intermiten atau nyeri yang berhubungan dengan lendir yang berlumuran darah, cairan vagina yang encer atau keluar aliran air tiba-tiba (Tanda-tanda persalinan prematur); Keputihan atau semburan air tibatiba dengan atau tanpa kram (ketuban pecah dini); perdarahan vagina dengan atau tanpa kram (perdarahan), dan sakit kepala parah (hipertensi).
2. Pemantauan ibu hamil pada minggu ke 24 dan 36 kehamilan oleh petugas kesehatan. Masingmasing petugas memantau 10 ibu hamil di komunitas menggunakan kartu pelacakan (tracking cards). Para ibu hamil juga diberikan pamflet sebagai pengingat.

3. Penentuan apakah ibu hamil positif memiliki tanda gejala prematur

4. Konfirmasi tanda gejala prematur oleh penyedia layanan kesehatan di primary health center (PHC) untuk menentukan kelayakan untuk mendapat ACT (Antenatal Corticosteroids) (Patel, Prakash, Pusdekar, Kulkarni, \& Hibberd, 2017). 
Tabel 1. Hasil Penelitian

\begin{tabular}{|c|c|c|c|c|c|c|c|c|c|c|c|c|}
\hline No. & $\begin{array}{c}\text { Nama } \\
\text { (Tahun) }\end{array}$ & Judul & Tujuan & Tempat & Metode & Sampel & $\begin{array}{c}\text { Teknik } \\
\text { Sampling }\end{array}$ & Instrumen & Kriteria Inklusi & Perlakuan & Hasil & Kesimpulan \\
\hline 1. & $\begin{array}{l}\text { (Ibrahim } \\
\text { et al., } \\
2010)\end{array}$ & $\begin{array}{l}\text { Progestero } \\
\text { ne } \\
\text { supplement } \\
\text { ation for } \\
\text { prevention } \\
\text { of preterm } \\
\text { labor: A } \\
\text { randomized } \\
\text { controlled } \\
\text { trial }\end{array}$ & $\begin{array}{l}\text { Untuk } \\
\text { mengevaluasi } \\
\text { peran program } \\
\text { intramusku-ler. } \\
\text { Terone (Cidolut } \\
\text { depot) dalam } \\
\text { pencegahan } \\
\text { prematurberula } \\
\text { ng tenaga kerja }\end{array}$ & Iran & RCT & $\begin{array}{l}50 \text { ibu } \\
\text { dengan } \\
\text { kehamilan } \\
\text { pertama } \\
\text { pada } \\
\text { trimester } \\
\text { kedua. } \\
\text { kelompok } \\
\text { intervensi } \\
25 \text { orang } \\
\text { dan } \\
\text { kelompok } \\
\text { control } 25 \\
\text { orang }\end{array}$ & $\begin{array}{c}\text { Quota } \\
\text { sampling }\end{array}$ & $\begin{array}{l}\text { Amplop } \\
\text { tertutup yang } \\
\text { berisi } 25 \\
\text { depot cidalut } \\
\text { dan } 25 \\
\text { placebo }\end{array}$ & $\begin{array}{l}\text { - Kehamilan } \\
\text { pertama trimester } \\
\text { kedua } \\
\text { - Riwayat } \\
\text { kebidanan } \\
\text {-Riwayat keluarga } \\
\text { dan sejarah masa } \\
\text { lalu } \\
\text {-Pemeriksaan } \\
\text { umum } \\
\text {-Pemeriksaan } \\
\text { kebidanan dan } \\
\text { USG }\end{array}$ & 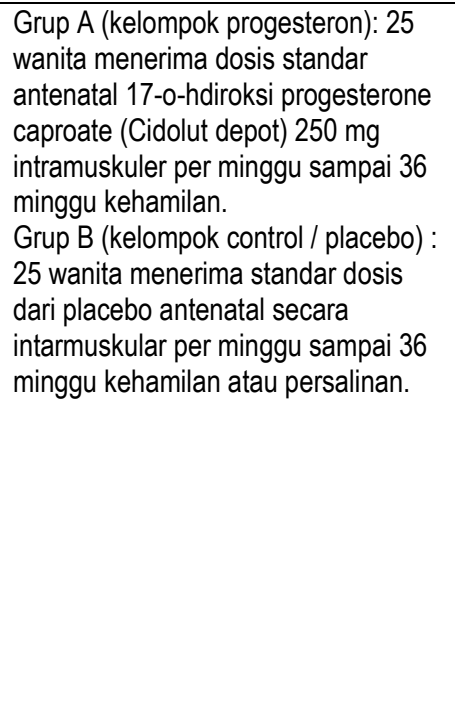 & $\begin{array}{l}\text { Usia kehamilan rata - } \\
\text { rata adalah } 37,4 \pm 15 \\
\text { pada kelompok } \\
\text { progesteron vs } 34,7 \pm \\
2,4 \text { pada kelompok } \\
\text { placebo ( } P<0,05) \text {. } \\
\text { Dalam kelompok } \\
\text { progesteron } 8 \text { dari } 25 \\
\text { wanita melahirkan } \\
\text { sebelum selesai } 37 \\
\text { minggu kehamilan } \\
(32 \%) \text { dan } 17 \text { wanita } \\
\text { melahirkan cukup bulan } \\
(68 \%) \text {. Pada kelompok } \\
\text { placebo, } 13 \text { dari } 25 \\
\text { wanita melahirkan } \\
\text { sebelum usia kehamilan } \\
37 \text { minggu }(52 \%) \text { dan } 12 \\
\text { wanita melahirkan cukup } \\
\text { bulan }(48 \%)\end{array}$ & $\begin{array}{l}\text { Temuan ini } \\
\text { mendukung 17- } \\
\text { o-hydroxy } \\
\text { progesterone } \\
\text { sebagai salah } \\
\text { satu } \\
\text { penatalaksanaa } \\
\text { n yang dapat } \\
\text { digunakan } \\
\text { dalam } \\
\text { mencegah dan } \\
\text { mengurangi } \\
\text { persalinan } \\
\text { prematur } \\
\text { berulang }\end{array}$ \\
\hline 2. & $\begin{array}{l}\text { (El- } \\
\text { Mohande } \\
\text { s et al., } \\
2010)\end{array}$ & $\begin{array}{l}\text { An } \\
\text { Intervention } \\
\text { to Reduce } \\
\text { Environme } \\
\text { ntal } \\
\text { Tobacco } \\
\text { Smoke } \\
\text { Exposure } \\
\text { Improves } \\
\text { Pregnancy } \\
\text { Outcomes }\end{array}$ & $\begin{array}{l}\text { Untuk menguji } \\
\text { efektivitas dari } \\
\text { perilaku-kognitif } \\
\text { (cognitive- } \\
\text { behavioural) } \\
\text { dalam } \\
\text { mengurangi } \\
\text { paparan asap } \\
\text { rokok } \\
\text { (environmental } \\
\text { tobacco smoke/ } \\
\text { ETSE) dan } \\
\text { meningkatkan } \\
\text { hasil kehamilan } \\
\text { pada wanita } \\
\text { enis kulit hitam }\end{array}$ & $\begin{array}{l}\text { Washin } \\
\text { gton DC }\end{array}$ & $\mathrm{RCT}$ & $\begin{array}{l}\text { Sample } \\
1044 \text { ibu } \\
\text { hamil yang } \\
\text { memenuhi } \\
\text { kriteria } \\
\text { penelitian. } \\
\text { Kelompok } \\
\text { intervensi } \\
521 \text { orang } \\
\text { dan } \\
\text { Kelompok } \\
\text { kontrol } 523 \\
\text { orang }\end{array}$ & $\begin{array}{c}\text { Total } \\
\text { sampling }\end{array}$ & $\begin{array}{l}\text { Hopkin's } \\
\text { Scale - bagi } \\
\text { penerima } \\
\text { terapi } \\
\text { cognitive- } \\
\text { behaviour } \\
\text { Conflict } \\
\text { Tactics scale } \\
\text { - bagi } \\
\text { wanita yang } \\
\text { mengalami } \\
\text { kekerasan } \\
\text { dari } \\
\text { pasangan } \\
\text { intimnya } \\
\text { (IPV) }\end{array}$ & $\begin{array}{l}\text { Etnis minoritas } \\
\text { Usia18 tahun } \\
\text { Usia kehamilan } 28 \\
\text { minggu } \\
\text { PendudukWashingt } \\
\text { on DC } \\
\text { Berbicara bahasa } \\
\text { Inggris } \\
\text { Memiliki minimal } 1 \\
\text { kriteria berikut: } \\
\text { merokok, ETSE, } \\
\text { depresi, kekerasan } \\
\text { (IPV). }\end{array}$ & $\begin{array}{l}\text { Intervensi untuk kelompok Intervensi: } \\
\text { Intervensi ETSE difokuskan pada } \\
\text { memperkenalkanstrategi dalam } \\
\text { rumah untuk menghilangkan atau } \\
\text { meminimalkan paparan ke ibu hamil } \\
\text { Ibu hamil yang diidentifikasi depresi di } \\
\text { intervensidengan terapi prilaku } \\
\text { kognitif } \\
\text { Untuk IVP menerima intervensi } \\
\text { berbasis brosur yang berfokus pada } \\
\text { pilihan untukmengembangkan } \\
\text { rencana keselamatan pribadi dan } \\
\text { daftar SDM yang dapat dihubungi. } \\
\text { Intervensi untuk kelompok kontrol: } \\
\text { - Perawatan biasa }\end{array}$ & $\begin{array}{l}\text { Dalam kasus bayi lahir } \\
\text { sangat prematur, ada } \\
\text { perbedaan yang } \\
\text { signifikan }(19,1 \% \text { vs } \\
49,5 \% ; P<01) \text {, dan } \\
\text { pada kasus bayi lahir } \\
\text { premature }(28,6 \% \text { vs } \\
11.1 \% ; P<01)\end{array}$ & $\begin{array}{l}\text { Intervensi yang } \\
\text { diberikan } \\
\text { secara } \\
\text { signifikan dapat } \\
\text { mengurangi } \\
\text { kelahiran bayi } \\
\text { sangat } \\
\text { prematur } \\
\text { setelah } \\
\text { disesuaikan } \\
\text { dengan } \\
\text { kebutuhan } \\
\text { sampel } \\
\text { kelompok yang } \\
\text { termasuk dalam } \\
\text { analisis ini. }\end{array}$ \\
\hline
\end{tabular}

Tetti Solehati*, Hana Giriutami, Meideline Chintya, Siti Haiva Alawiyah, Selvia Nurfauzan, Riftania Aulia Puri, Muhammad lqbal Assafa, Cecep Eli Kosasih

Fakultas Keperawatan Universitas Padjadjaran Bandung Jawa Barat.*Email: tetti.solehati@unpad.ac.id 
Intervensi selama kehamilan untuk mencegah kelahiran prematur: Systematic literature review

\begin{tabular}{|c|c|c|c|c|c|c|c|c|c|c|c|c|}
\hline 3. & $\begin{array}{l}\text { (Patel, } \\
\text { Prakash, } \\
\text { Pusdekar } \\
\text { Kulkarni, } \\
\text { \& } \\
\text { Hibberd, } \\
\text { 2017a) }\end{array}$ & $\begin{array}{l}\text { Detection } \\
\text { and risk } \\
\text { stratificatio } \\
\mathrm{n} \text { of women } \\
\text { at high risk } \\
\text { of preterm } \\
\text { birth in } \\
\text { rural } \\
\text { communitie } \\
\text { s near } \\
\text { Nagpur, } \\
\text { India }\end{array}$ & $\begin{array}{l}\text { Untuk } \\
\text { mengurangi } \\
\text { kematian } \\
\text { neonatal karena } \\
\text { kelahiran } \\
\text { prematur. }\end{array}$ & $\begin{array}{l}\text { Komunit } \\
\text { as } \\
\text { pedesa } \\
\text { an } \\
\text { dekat } \\
\text { Nagpur, } \\
\text { India }\end{array}$ & $\begin{array}{l}\text { Cluster } \\
\text { randomi } \\
\text { zed trial }\end{array}$ & $\begin{array}{l}15120 \\
\text { wanita } \\
\text { hamil } \\
\text { Kelompok } \\
\text { control: } \\
7692 \\
\\
\text { Kelompok } \\
\text { intervensi: } \\
7050\end{array}$ & $\begin{array}{l}\text { Cluster } \\
\text { sampling }\end{array}$ & $\begin{array}{l}\text { Tracking } \\
\text { cards }\end{array}$ & $\begin{array}{l}\text { Wanita yang } \\
\text { terdaftar di } \\
\text { Maternal Newborn } \\
\text { Health (MNH) } \\
\text { Registry sebelum } \\
\text { memasuki usia } \\
\text { kehamilan } 24 \\
\text { minggu }\end{array}$ & $\begin{array}{l}\text { Kelompok Intervensi } \\
\text { Terdiri dari } 4 \text { komponen: } \\
\text { Pelatihan petugas kesehatan } \\
\text { Pemantauan ibu hamil oleh petugas } \\
\text { kesehatan } \\
\text { Penentuan apakah ibu hamil positif } \\
\text { memiliki tanda gejala prematur } \\
\text { Konfirmasi tanda gejala prematur oleh } \\
\text { penyedia layanan kesehatan di } \\
\text { primary health center } \\
\text { Kelompok kontrol: } \\
\text { Tidak diberi perlakuan pemantauan } \\
\text { kehamilan oleh petugas kesehatan. }\end{array}$ & $\begin{array}{l}\text { Dari } 7050 \text { wanita yang } \\
\text { diteliti, } 732(10,4 \%) \\
\text { wanita positif HRPB } \\
\text { (High risk preterm birth). } \\
\text { Kemudian dari } 732 \mathrm{di} \\
\text { antaranya } 333(45,5 \%) \\
\text { melahirkan prematur. } \\
\text { Dari } 6318 \text { sisanya } \\
(89,6 \%) \text { wanita HRPB } \\
\text { negatif } 353(5,6 \%) \\
\text { melahirkan prematur. } \\
\text { LR kelahiran prematur } \\
\text { meningkat pada wanita } \\
\text { yang memiliki lebih } \\
\text { banyak tanda atau } \\
\text { gejala HRBP (p } \\
<0,00001) . \\
\text { Prevalensi keseluruhan } \\
\text { kelahiran prematur di } \\
\text { komunitas ini adalah } \\
10 \% \text {, lebih rendah dari } \\
\text { prevalensi prematur } \\
\text { yang dilaporkan di India } \\
\text { yaitu } 13 \% \text {. }\end{array}$ & $\begin{array}{l}\text { Paket untuk } \\
\text { deteksi tanda } \\
\text { dan gejala } \\
\text { HRPB layak, } \\
\text { menjanjikan } \\
\text { dan } \\
\text { kemungkinan } \\
\text { besar } \\
\text { memperbaiki } \\
\text { manajemen } \\
\text { persalinan } \\
\text { prematur }\end{array}$ \\
\hline
\end{tabular}

Tetti Solehati*, Hana Giriutami, Meideline Chintya, Siti Haiva Alawiyah, Selvia Nurfauzan, Riftania Aulia Puri, Muhammad lqbal Assafa, Cecep Eli Kosasih

Fakultas Keperawatan Universitas Padjadjaran Bandung Jawa Barat. ${ }^{*}$ Email: tetti.solehati@unpad.ac.id 


\section{PEMBAHASAN}

\section{Terapi Suplementasi Progesteron}

Dalam penelitian Ibrahim et al (2010), menyatakan adanya perbedaan yang signifikan terkait usia gestasional pada kelompok kontrol yang menerima terapi 17-(-hydroxyprogesterone caproate dibandingkan dengan kelompok bebas yang diberikan plasebo dengan 37.47 (1.559 dan 34.71 ( 2.49 menunjukkan $P<0.05$. Progesteron merupakan steroid sex yang disekresikan dari korpus luteum setelah ovulasi. Jika telah mencapai pembuahan, maka korpus luteum akan bekerja. Progesterone diperlukan untuk mempertahankan kehamilan sampai sekitar 10 minggu kehamilan, setelah itu plasenta akan bertanggung jawab untuk memproduksi hormone progesterone (Maggio \& Rouse, 2014). Selama kehamilan, pregesteron berperan penting dalam perkembangan fetus, menstimulasi pertumbuhan jaringan payudara maternal, mencegah laktasi dan menguatkan dinding otot pelvis untuk mempersiapkan kelahiran. 17-(-hydroxyprogesterone caproate (OHPC) merupakan sintesa dari hormone progestin. Selama kehamilan, 17-(-hydroxyprogesterone di produksi di kelenjar adrenal. Penggunaan OHPC pada kehamilan untuk mencegah kelahiran premature pada wanita yang sebelumnya memiliki riwayat persalinan premature antara 20 minggu dan 36 minggu (Norton, Chauhan, Dashe, \& Medicine, 2015). Hasil penelitian ini sesuai dengan penelitian lain yang melaporkan hasil uji coba dari progesteron 17-(-hydroxyprogesterone caproate yang dilakukan oleh Maternal Fetal Medicine Units Network of the National Institute of Child Health and Human Development (Meis et al., 2003).

Penelitian ini melibatkan wanita dengan dokumentasi riwayat persalinan preterm spontan, yang terjadi sebagai akibat ruptur dari membran janin. Para pasien secara acak diberikan suntikan mingguan $250 \mathrm{mg}$ caproate 17-a-hydroxy progesterone atau injeksi plasebo. Dalam penelitian itu, persalinan kurang dari 37 minggu berkurang dari $54,9 \%$ pada kelompok plasebo menjadi $36,3 \%$ pada kelompok perlakuan. Pengurangan serupa terlihat dalam kelahiran kurang dari 35 minggu, dari 30,7\% menjadi 20,6\% dan kelahiran kurang dari 32 minggu dari 19,6\% menjadi $11,4 \%$.

Pemberian17-(-hydroxyprogesterone caproate sebagai penyokong progesterone membantu menyokong usia gestasional dengan mekanisme mengurangi tingkat pemendekan serviks pada wanita dengan riwayat melahirkan premature (O'brien et al., 2009). Temuan lain menyatakan suplementasi progesterone menurunkan resiko kelahiran prematur pada wanita asimtomatik dengan serviks yang pendek (Hassan et al., 2011). Progesterone juga dihubungkan dengan reduksi frekuensi kontraksi uterin (Anderson, Martin, Higgins, Nelson, \& Norman, 2009).

\section{Intervensi pengurangan paparan asap rokok pada lingkungan dengan terapi perilaku kognitif (Cognitive-Behavioural Teraphy)}

Pada penelitian El-Mohandes et al. (2010), terdapat perbedaan signifikan terkait kelahiran prematur pada wanita yang terpapar asap rokok antara kelompok intervensi dan kelompok control dengan perbedaan $P<0,05$. Paparan nikotin dari asap rokok meningkatkan resiko perburukan kesehatan bagi janin. Baik perokok aktif maupun lingkungan dengan paparan asap rokok (tembakau) dapat memperburuk kondisi kehamilan seperti kematian neonatus, kelahiran prematur, berat badan bayi lahir rendah (BBLR) dan sindrom kematian janin secara tiba-tiba (Roelands, Jamison, Lyerly, \& James, 2009). Paparan asap rokok harus dianggap berbahaya, tidak hanya bagi perokok aktif, tapi juga bagi perokok pasif. Bagi ibu hamil, sangatlah penting untuk tidak terpapar asap rokok, karena selain mengakibatkan kejadian seperti yang disebutkan sebelumnya, pertumbuhan dan perkembangan janin pun juga dapat terganggu dengan paparan asap rokok ini. Penelitian terkait pengurangan asap rokok di lingkugan untuk memperbaiki kualitas kehamilan masih sangat sedikit, deperlukan penelitian lebih lanjut guna membuktikan keefektifan dari intervensi yang dilakukan.

\section{Identifikasi dan Penatalaksaan Secara Cepat Terhadap Ibu Hamil Yang Beresiko Tinggi Lahir Prematur (HRPB)}

Menurut Patel et al. (2017), melakukan identifikasi dini terhadap ibu hamil beresiko tinggi lahir premature (HRPB) serta melakukan tindakan secepat mungkin setelah dilakukan identifikasi dapat mencegah kelahiran premature yang saat ini menjadi penyebab utama kematian neonatal. Dalam pelaksanaannya sendiri ibu hamil akan diberitahukan mengenai 4 tanda dan gejala dari kelahiran premature, namun menurut saya dalam pelaksanaan secara real nya tidak menutup kemungkinan untuk melibatkan semua pihak dalam

Tetti Solehati*, Hana Giriutami, Meideline Chintya, Siti Haiva Alawiyah, Selvia Nurfauzan, Riftania Aulia Puri, Muhammad lqbal Assafa, Cecep Eli Kosasih

Fakultas Keperawatan Universitas Padjadjaran Bandung Jawa Barat.*Email: tetti.solehati@unpad.ac.id 
hal ini, dalam artian masyarakat di lingkungannya pun diberikan pendidikan kesehatan dan turut andil dalam mengidentifikasi atau untuk sekedar saling mengingatkan terhadap ibu hamil di lingkungannya. Setelah pengenalan 4 tanda dan gejala kelahiran prematur diberikan, tiap individu memiliki tanggung jawab pribadi untuk melakukan identifikasi, setelah proses identifikasi berjalan dan kemudian diketahui misalkan ada salah seorang ibu hamil yang memiliki 1 atau lebih dari tanda dan gejala kelahiran prematur makan bisa langsung dirujuk ke pelayanan kesehatan pemerintah terdekat untuk dilakukan penilaian dan manajemen. Adapun $p$ value dari penelitian ini adalah $<0,00001$.

Pada dasarnya identifikasi dini terhadap ibu hamil untuk mencegah kelahiran premature adalah hal yang penting untuk dilakukan. Menurut Newnham et al. (2017), tes skrining dapat dikembangkan untuk mengidentifikasi individu dengan aktivasi kelahiran prematur pada tahap dimana pengobatan dapat membalikan aktivasi tersebut sebelum titik kritis persalinan prematur menjadi tak terelakkan (berdasarkan pendekatan transkriptomi). Selain itu variasi proteomik dapat mengirim atau menunjukan tanda awal sebelum pengembangan gejala yang terlihat secara klinis (berdasarkan pendekatan proteomik) (Newnham et al., 2017).

Dengan demikian, identifikasi dini terhadap ibu hamil sangat efektif untuk mencegah kelahiran prematur. Dimana semakin cepat kita menyadari tanda dan gejala yang ada atau kita waspada terhadap kondisi diri kita sendiri maka kemungkinan angka kelahiran premature dapat menurun dan dapat mengurangi kematian pada neonatal. Identifikasi dini dalam hal ini tidak semuanya dapat dikatakan sama, dalam artian identifikasi dini ini di kehidupan secara nyatanya dapat berupa pengetahuan yang dimiliki oleh ibu hamil ataupun masyarakat (yang didapatkan melalui pendidikan kesehatan oleh tenaga medis atau informasi yang didapatkan melalui media sosial) juga dapat berupa beberapa tes kesehatan atau screening yang dilakukan oleh ibu hamil.

Pentingnya pertumbuhan bayi prematur yaitu menerima perhatian, stimulasi untuk perkembangan jangka panjang. Akan tetapi, pertumbuhan sering merupakan masalah sekunder saat perawatan paska lahir karena yang diutamakan adalah pada stabilitas dan pengelolaan penyakit akut. Seorang perawat harus memberikan stimulasi ritmik yang lembut bentuk sentuhan lembut, pijatan, memeluk, membelai dan melenturan stimulus pendengaran yang menenankan dapat diberikan pada bayi prematur dalam bentuk suara dari keluarga atau musik (Fayed, 2016).

Dari ketiga intervensi tersebut telah terbukti dalam pencegahan kelahiran premature selama masa kehamilan. Sayangnya tidak di dukung dengan pelibatan keluarga pasien, dimana keluarga dapat berperan sebagai supporter bagi ibu hamil dalam melaksanakan intervensi yang petugas berikan.

\section{SIMPULAN}

Intervensi yang secara efektif dapat diberikan dalam pencegahan kelahiran bayi prematur pada ibu hamil dapat dilakukan dengan pemberian suplemen hydroxyprogesteron caproate, pengurangan paparan asap rokok di lingkungan ibu hamil, dan penatalaksanaan secara cepat oleh petugas kesehatan dengan cara deteksi dini terhadap ibu hamil yang berisiko tinggi terhadap kelahiran premature.

\section{SARAN}

Berdasarkan hasil penelitian, belum ditemukan adanya dukungan keluarga yang dilibatkan dalam intervensi pencegahan kelahiran premature, maka disarankan untuk penelitian selanjutnya untuk melakukan penelitian yangmelibatkan keluarga dalam intervensi pencegahan kelahiran premature.

\section{DAFTAR PUSTAKA}

Anderson, L., Martin, W., Higgins, C., Nelson, S. M., \& Norman, J. E. (2009). The effect of progesterone on myometrial contractility, potassium channels, and tocolytic efficacy. Reproductive sciences, 16(11), 1052-1061.

El-Mohandes, A. A., Kiely, M., Blake, S. M., Gantz, M. G., \& El-Khorazaty, M. N. (2010). An intervention to reduce environmental tobacco smoke exposure improves pregnancy outcomes. Pediatrics, 125(4), 721-728.

Fayed, N. M. (2016). Effect of Physical Stimulation on Premature Very Low Birth Weight Infants. American Journal of Nursing Research, 4(1), 612.

Tetti Solehati*, Hana Giriutami, Meideline Chintya, Siti Haiva Alawiyah, Selvia Nurfauzan, Riftania Aulia Puri, Muhammad lqbal Assafa, Cecep Eli Kosasih

Fakultas Keperawatan Universitas Padjadjaran Bandung Jawa Barat.*Email: tetti.solehati@unpad.ac.id 
Hutchins, S. S., Brown, C., Mayberry, R., \& Sollecito, W. (2015). Value of a small control group for estimating intervention effectiveness: results from simulations of immunization effectiveness studies. Journal of comparative effectiveness research, 4(3), 227-238.

Ibrahim, M., Ramy, A. R. M., \& Younis, M. A.-F. (2010). Progesterone supplementation for prevention of preterm labor: a randomized controlled trial. Middle East Fertility Society Journal, 15(1), 39-41.

Institute, J. B. (2017). The Joanna Briggs Institute Critical Appraisal tools for use in JBI systematic reviews. Checklist for Randomized Controlled Trials.

Lassi, Z. S., Middleton, P. F., Crowther, C., \& Bhutta, Z. A. (2015). Interventions to improve neonatal health and later survival: an overview of systematic reviews. EBioMedicine, 2(8), 9851000.

Maggio, L., \& Rouse, D. J. (2014). Progesterone. Clinical obstetrics and gynecology, 57(3), 547556.

Medley, N., Vogel, J. P., Care, A., \& Alfirevic, Z. (2018). Interventions during pregnancy to prevent preterm birth: an overview of Cochrane systematic reviews. Cochrane Database of Systematic Reviews(11).

Meis, P. J., Klebanoff, M., Thom, E., Dombrowski, M. P., Sibai, B., Moawad, A. H., \& Varner, M. W. (2003). Prevention of recurrent preterm delivery by 17 alpha-hydroxyprogesterone caproate. New England Journal of Medicine, 348(24), 2379-2385.

Moher, D., Liberati, A., Tetzlaff, J., \& Altman, D. G. (2009). Preferred reporting items for systematic reviews and meta-analyses: the PRISMA statement. Annals of internal medicine, 151(4), 264-269.
Newnham, J. P., Kemp, M. W., White, S. W., Arrese, C. A., Hart, R. J., \& Keelan, J. A. (2017). Applying precision public health to prevent preterm birth. Frontiers in public health, 5,66 .

Noriani, N. K., Putra, I. A. E., \& Karmaya, M. (2015). Paparan asap rokok dalam rumah terhadap risiko peningkatan kelahiran bayi prematur di Kota Denpasar. Public Health and Preventive Medicine Archive, 3(1), 68-73.

Norton, M. E., Chauhan, S. P., Dashe, J. S., \& Medicine, S. f. M.-F. (2015). Society for maternal-fetal medicine (SMFM) clinical guideline\# 7: nonimmune hydrops fetalis. American journal of obstetrics and gynecology, 212(2), 127-139.

O'brien, J., Defranco, E., Adair, C., Lewis, D., Hall, D., How, H., \& Creasy, G. (2009). Effect of progesterone on cervical shortening in women at risk for preterm birth: secondary analysis from a multinational, randomized, double-blind, placebo-controlled trial. Ultrasound in Obstetrics and Gynecology, 34(6), 653-659.

Patel, A., Prakash, A. A., Pusdekar, Y. V., Kulkarni, H., \& Hibberd, P. (2017). Detection and risk stratification of women at high risk of preterm birth in rural communities near Nagpur, India. BMC pregnancy and childbirth, 17(1), 311.

Roelands, J., Jamison, M. G., Lyerly, A. D., \& James, A. H. (2009). Consequences of smoking during pregnancy on maternal health. Journal of Women's Health, 18(6), 867-872.

WHO. (2018). Preterm birth Retrieved April 7, 2020, 2020, from https://www.who.int/newsroom/fact-sheets/detail/preterm-birth

Zhang, Y.-P., Liu, X.-H., Gao, S.-H., Wang, J.-M., Gu, Y.-S., Zhang, J.-Y., \& Li, Q.-X. (2012). Risk factors for preterm birth in five Maternal and Child Health hospitals in Beijing. PLOS One, 7(12). 